\title{
Plastic patterns in larval development of Endangered endemic Atelognathus patagonicus: implications for conservation strategies
}

\author{
María E. Cuello ${ }^{1, *}$, Carmen A. Úbeda ${ }^{1}$, María T. Bello ${ }^{1}$, María G. Perotti ${ }^{2}$ \\ ${ }^{1}$ Centro Regional Bariloche, Universidad Nacional del Comahue, Quintral 1250, 8400 San Carlos de Bariloche, Argentina \\ ${ }^{2}$ Laboratorio de Fotobiología, INIBIOMA (CRUB-UNCo-CONICET), Quintral 1250, 8400 San Carlos de Bariloche, Argentina
}

\begin{abstract}
The Patagonia frog Atelognathus patagonicus (Anura, Ceratophryidae) is endemic to north-western Patagonia where it inhabits permanent and temporary water bodies in a system of endorheic ponds on the basaltic plateau in and around Laguna Blanca National Park, northwestern Patagonia, Argentina. This Endangered species is emblematic of the decline and extinction of amphibian populations as a result of the introduction of fish to Laguna Blanca. Therefore, the aims of this study were to determine the patterns of larval development in ponds with different hydroperiods and to evaluate the occurrence of different developmental strategies and their implications for conservation management. In permanent ponds, A. patagonicus tadpoles showed a double strategy, with the presence of both seasonal (short larval period; metamorphs in the same growing season) and overwintering tadpoles (undergoing metamorphosis the following spring). In temporary ponds, desiccation seems to exert great pressure, with accelerated larval development, resulting in short larval periods. Atelognathus patagonicus showed plasticity in the length of larval development, adjusting to the different hydroperiods observed in these wetlands. As a result of this dual strategy, overwintering tadpoles in permanent ponds are larger than seasonal tadpoles. This notable plasticity in developmental strategy enables this species to colonize widely varying environments. These results highlight the importance of preserving a variety of wetlands, including both temporary and permanent ponds, to allow this species to continue to breed and develop in the face of current and potential anthropogenic disturbance, in particular that caused by the activity of local native pastoralists.
\end{abstract}

KEY WORDS: Atelognathus patagonicus $\cdot$ Endangered species $\cdot$ Larval strategies $\cdot$ Developmental plasticity $\cdot$ Conservation $\cdot$ Threatened habitat $\cdot$ Patagonia

\section{INTRODUCTION}

The life histories of species that exploit different habitats vary widely. Amphibians use a variety of aquatic habitats, ranging from permanent to ephemeral bodies of water (Werner \& McPeek 1994). The hydroperiod gradient affects amphibian larval development and survival (Semlitsch 1987, Pechmann et al. 1989) and determines the time available for completing metamorphosis. Amphib- ians that use temporary environments have life cycles that are synchronized to the pattern of filling and desiccation of the pond (Griffiths 1997), and their larval development period may vary according to how long the water remains in the pond (Wilbur \& Collins 1973). This is true of the larvae of some anuran species which, in response to pond drying, have accelerated development rates at the expense of growth in order to ensure metamorphosis to the terrestrial phase before all 
the water is lost (Crump 1989, Newman 1989, Laurila \& Kujasalo 1999, Perotti et al. 2011).

Permanent ponds are more stable environments in terms of hydroperiod duration, and most tadpoles can remain in these ponds for a long time until they reach the optimum size for metamorphosis (Wilbur \& Collins 1973), suggesting that temperature may be sufficiently low to make overwintering of larvae obligatory (Berven et al. 1979, Collins 1979, Collins \& Lewis 1979, Smith-Gill \& Berven 1979). In permanent ponds, the time over which larvae complete their growth and development may range from a few months to a year or even longer (Wilbur \& Collins 1973, Viparina \& Just 1975, Úbeda et al. 1999).

The endemic frog Atelognathus patagonicus (Gallardo, 1962) lives in permanent and temporary water bodies in a system of fish-free endorheic ponds on the basaltic plateau in Laguna Blanca National Park and surroundings in north-western Argentinean Patagonia (Cuello et al. 2009a). The distribution of $A$. patagonicus is restricted to one of the harshest habitats of the Patagonian steppe, with long winters during which the surface of water bodies remains frozen and covered in snow for several months of the year (June to August). A. patagonicus tadpoles are thus exposed to extreme habitat conditions which mean that they have to overwinter. This species is emblematic of the decline and extinction of amphibian populations. It is classified as Endangered by the IUCN (Úbeda et al. 2010), and was reported as having disappeared from Laguna Blanca, the type locality and the main water body in this system, as a result of the introduction and translocation of fish species during the 1940s to 1960s (Administración de Parques Nacionales 1993, Ortubay et al. 2006a,b, Úbeda et al. 2010).

The introduced or translocated fish species Percichthys colhuapiensis and $P$. trucha (Percichthyidae), Oncorhynchus mykiss and Salmo trutta (Salmonidae), Galaxias maculatus (Galaxiidae) and Jenynsia multidentata (Jenynsidae) (Daciuk 1968, Gallardo 1979, Ortubay et al. 2006b) resulted in significant negative changes in the native aquatic biota. (Mazzucchelli 1991, Administración de Parques Nacionales 1993, Ortubay et al. 2006a,b). The most severe impact is attributed to $P$. colhuapiensis, a species whose colonization was highly successful and responsible for the environmental changes that led to the disappearance of Atelognathus patagonicus (Administración de Parques Nacionales 1993, Ortubay et al. 2006a, Cuello et al. 2006). Today, P. colhuapiensis is the most plentiful fish species in Laguna Blanca.
Another type of disturbance is caused by the activity of a group of 'crianceros' - local native pastoralists. This kind of activity is typical of the agroecological system in the Andes of northern Argentine Patagonia, and has been documented ever since the first studies were conducted in the area (Daciuk 1968). Livestock, mainly sheep and goats, cause considerable environmental alteration due to overstocking and the free movement of animals (Daciuk 1968, Administración de Parques Nacionales 1993). Horses and cattle, in particular, go into ponds and feed on macrophytic plants, causing the loss of sites used by much of the aquatic biota, including Atelognathus patagonicus, for shelter, feeding and/or breeding.

Nomadic livestock raising is also practiced, in which large herds cross the national park and stop for water at ponds inhabited by Atelognathus patagonicus (Daciuk 1968, Administración de Parques Nacionales 1993). In the habitats on the shore of the pond that provide tender grass and easy access to water, overgrazing and trampling reduce the plant cover and increase erosion. In addition, a major increase in organic matter from feces and urine has been recorded (Mazzucchelli 1991, Administración de Parques Nacionales 1993, Basso et al. 2012).

Within this context, it is essential to determine the life history and fluctuation of population parameters of Atelognathus patagonicus, as well as the climate and hydroperiod factors that may affect this species, in order to take adequate and timely action for its conservation.

There is little knowledge of the biology of Atelognathus patagonicus (Cei \& Roig 1966, Cuello et al. 2006, 2008, 2009b), especially regarding the species' larval period (Cuello \& Perotti 2006). The overall aim of the present study was to determine the patterns of larval development of $A$. patagonicus in ponds with different hydroperiods to provide information for conservation measures for this species and its habitats. The specific aims were to determine: (1) whether there are differences among the patterns of larval development for populations in temporary and permanent environments, and (2) whether the relative abundance of the different larval stages over time is related to environmental parameters of the wetlands, such as water temperature, depth and hydroperiod.

\section{MATERIALS AND METHODS}

\section{Study area}

We studied the development pattern of 2 populations of Atelognathus patagonicus inhabiting 2 wet- 
lands that differed in hydroperiod: Batea Pond (temporary) and Verde Pond (permanent), both located in Laguna Blanca National Park, Neuquén Province, Argentina. These ponds represent the extremes of the natural hydroperiod range that is suitable for the breeding of this species.

Batea Pond $\left(39^{\circ} 2^{\prime} 2^{\prime \prime} \mathrm{S}, 70^{\circ} 24^{\prime} 31^{\prime \prime} \mathrm{W}\right.$; $1288 \mathrm{~m}$ elevation) is located in a flat depression partly surrounded by mechanically fragmented basalt and volcanic bombs. Water filters into it through the basalt basin. The pond is deepest in spring as a result of the runoff from rainfall and snowmelt, and shallowest in late summer. Its level varies noticeably from year to year: records show a maximum depth of $2.7 \mathrm{~m}$ and a maximum surface area of 2.5 ha in late spring 2004 (Cuello et al. 2008), while minimum depths range from $10 \mathrm{~cm}$ in years with little precipitation to 50$60 \mathrm{~cm}$ in years with plentiful precipitation (Cuello et al. 2008). When the pond is at its shallowest, a muddy residue remains and there is low oxygen content, high temperature, high turbidity and a smell of hydrogen sulphide due to the death and decomposition of macrophytic vegetation and associated communities. The pond dried up completely in late summer 1999, recovering the following spring; this seasonal variation occurred again in each of the years 2007 to 2010. Metamorph recruitment was found in all cases (M.E.C. \& C.A.Ú. pers. obs.).

During winter, the surface of Batea Pond freezes. The lowest water temperatures at the sampling sites were recorded in late fall $\left(0.05^{\circ} \mathrm{C}\right.$, May 2005), and the highest in late summer $\left(25^{\circ} \mathrm{C}\right.$, February 2005). Most of the shore $(75 \%)$ is characterized by herbaceous hydrophilic vegetation (grasses, rushes and sedges) and is covered in fine clay sediment, while the rest is covered in fine sediment with scattered volcanic rocks. The rooted macrophyte Myriophyllum quitense emerges from the pond, covering the entire pond surface when the water volume decreases. Some migratory aquatic birds are observed sporadically.

At the other end of the water permanency gradient is Verde Pond ( $39^{\circ} 01^{\prime} \mathrm{S}, 70^{\circ} 23^{\prime} \mathrm{W}, 1250$ m elevation), located $3.5 \mathrm{~km}$ northeast of Batea Pond. It is a permanent pond with a maximum surface area of 21.2 ha (October 2005) and a minimum of 15.2 ha (April 2006). It is located in a flat basin and its maximum depth $(4.5 \mathrm{~m})$ was recorded in February 2004 and January 2006. It freezes over during winter, and water temperatures range from $0.08^{\circ} \mathrm{C}$ (June 2005) to $27^{\circ} \mathrm{C}$ (February 2005). About $40 \%$ of the shore is gently sloping and covered with large overlapping rocks $(\geq 45 \mathrm{~cm}) ; 30 \%$ is covered with fine sediment, while the rest is characterized by grasses, rushes and sedges. The water is turbid due to suspended particles, microscopic algae and feces of the numerous waterbirds that live in the pond from November to April. There are also spherical colonies of Nostoc commune and rooted macrophytes such as Myriophyllum quitense and Zannichellia palustris. Emerging macrophytes are usually found in a ring parallel to the shore during summer and fall.

The climate in the region is arid, with warm summers with little or no rainfall, and cold winters with heavy frost, snow and rain mainly from May to October. Annual rainfall from 1999 to 2005 ranged from 82 to $344 \mathrm{~mm}$ (Zapala Airport Meterological Station, Neuquén Province). Westerly winds are frequent and particularly strong and dry in spring and summer.

\section{Tadpoles and metamorphs}

Surveys of larval development of Atelognathus patagonicus were conducted once a month at both locations: Batea Pond from November 2004 to May 2006, with the exception of July and August 2004 due to the accumulation of ice and snow on the pond surface; and Verde Pond from April 2004 to May 2006.

Sampling was stratified according to the ponds' environmental diversity and surface areas. The sampling effort (number of traps) was distributed proportionally to the size of these sampled areas. At Batea Pond, 2 sectors were considered: (1) areas covered in a mixture of sediment types (coarse fragments, isolated volcanic bombs and fine sediment) and (2) areas covered in fine sediment only (predominantly clay with some sand). At Verde Pond, 3 representative sectors were considered: (1) areas covered in coarse fragments (large rocks, some nearly $1 \mathrm{~m}$ in diameter, piled upon each other), (2) areas covered in fine sediment (mainly sand) and (3) mixed areas (a combination of coarse fragments and slab-shaped rocks, generally $<50 \mathrm{~cm}$, and fine sediment, mainly sand), with occasional presence of Miriophyllum quitense.

In each sector of each pond, we placed 30 subaquatic plastic funnel traps $(11 \mathrm{~cm}$ diameter, $30 \mathrm{~cm}$ long) with a single funnel, to make a total 60 traps in Batea Pond and 90 traps in Verde Pond. Traps were placed at the bottom of the ponds parallel to the shoreline from 0.2 to $0.8 \mathrm{~m}$ depth at $5 \mathrm{~m}$ intervals, and left undisturbed overnight. All sampling sessions lasted from late afternoon to early morning.

Pilot sampling showed that due to the particular characteristics of Batea Pond, 2 sampling methods needed to be combined: subaquatic traps and tran- 
sects. We therefore set up 3 parallel band transects along the shoreline; the transects $(50 \mathrm{~m}$ long and $2 \mathrm{~m}$ wide) included both water and land.

Specimens collected during field work were counted, developmental stage was recorded (Gosner 1960) with the aid of a magnifying glass (8x), and body length (BL) was measured with a Vernier caliper (reading error $0.05 \mathrm{~mm}$ ). After measurements were taken, frogs were released at the sites of capture.

In order to classify the specimens, 5 development classes were considered for tadpoles and one for metamorphs, by grouping into Gosner stages (Gosner 1960): (1) tadpoles: Class I (Stages 26-30), Class II (Stages 31-34), Class III (Stages 35-37), Class IV (Stages 38-41) and Class V (Stages 42-45); and (2) metamorphs: Class VI (Stage 46).

Two types of tadpoles were distinguished according to the strategy used to reach metamorphosis: (1) seasonal tadpoles, which completed their development within 1 growth season, and (2) overwintering tadpoles, which metamorphosed during the growth season after the season in which they hatched (Cuello \& Perotti 2006). We determined whether tadpole strategy was seasonal or overwintering by analyzing the distribution of stages and sizes observed over the entire study period, considering that overwintering tadpoles grow to larger sizes compared with seasonal tadpoles at the same stages (Class V, seasonal tadpoles, mean $\pm 1 \mathrm{SD}: 22.9 \pm 1.7 \mathrm{~mm}$; overwintering tadpoles: $25.1 \pm 1.5 \mathrm{~mm}$ ).

For logistic reasons, tadpole BL was measured from a representative sub-sample of 30 ind. at each sector, providing a total for each sample of 60 ind. from Batea Pond and 90 from Verde Pond.

At both ponds, all the specimens captured with subaquatic traps during each monthly sampling session were treated as a single sample. Relative abundance was expressed as individuals per trap, and the monthly records enabled an estimate of the relative abundance $(\%)$ for each development class in each pond.

To test whether there were differences in the number of individuals per trap between different periods and months within each pond, we used a nonparametric Kruskal-Wallis test (since the data did not meet the assumptions of normality), and an a posteriori Tukey test (multiple comparisons method). At Batea Pond, the months with captures were considered for analysis. Abundance was compared between years, months and development classes for both ponds, corresponding to the periods November 2004-April 2005 versus November 2005-April 2006 for Batea Pond, and April 2004-March 2005 versus April 2005-March 2006 for Verde Pond.

The size (BL) of Class V tadpoles was compared between seasonal tadpoles and overwintering tadpoles using the Student's t-test or the Mann-Whitney $U$-test. The same procedure was used to compare the BL of the metamorphs of seasonal tadpoles and overwintering tadpoles.

\section{Environmental variables}

Maximum depth was recorded monthly at Batea Pond using a stake graduated in centimeters and twice at Verde Pond (February 2004 and January 2006) by hanging a weighted rope from a boat.

To collect hourly temperature at each pond, a data logger (HOBO Water Temp Pro) was installed at a depth of 0.5 to $0.8 \mathrm{~m}$. An extra data logger was installed at Verde Pond (2 m depth) from April 2004 to July 2005.

A non-parametric Spearman test (Krebs 1989) was used to analyze the relationship among environmental parameters (mean monthly water temperatures, depth at Batea Pond and precipitation in the area) and the relative abundance of each development class in each pond.

\section{RESULTS}

At Batea Pond, tadpoles completed their development within a single growth season, between spring and early autumn, during which all the development classes were recorded (Fig. 1B,C). No tadpoles or metamorphs were captured in winter. The duration of the larval period recorded differed between the growth seasons 2004-2005 and 2005-2006 (6 and $4 \mathrm{mo}$, respectively; Fig. 1B,C). Overall, the relative abundance of individuals differed significantly between development classes and between sampling periods and months (Kruskal-Wallis test, $H=189.59$, $\mathrm{p}<0.001)$. The largest number of tadpoles was captured in subaquatic traps $(\mathrm{n}=231)$ in December 2004, and included tadpoles of Classes II, III and IV (Fig. 1B), while the highest number of metamorphs $(n=56)$ was captured with the transect method at the end of the first growth season (March 2005; Fig. 1C).

The same development classes were recorded in November and December for both periods, whereas as from January their monthly occurrence differed (Fig. 1B). The relative frequency of development classes also differed between periods. Metamorphs 


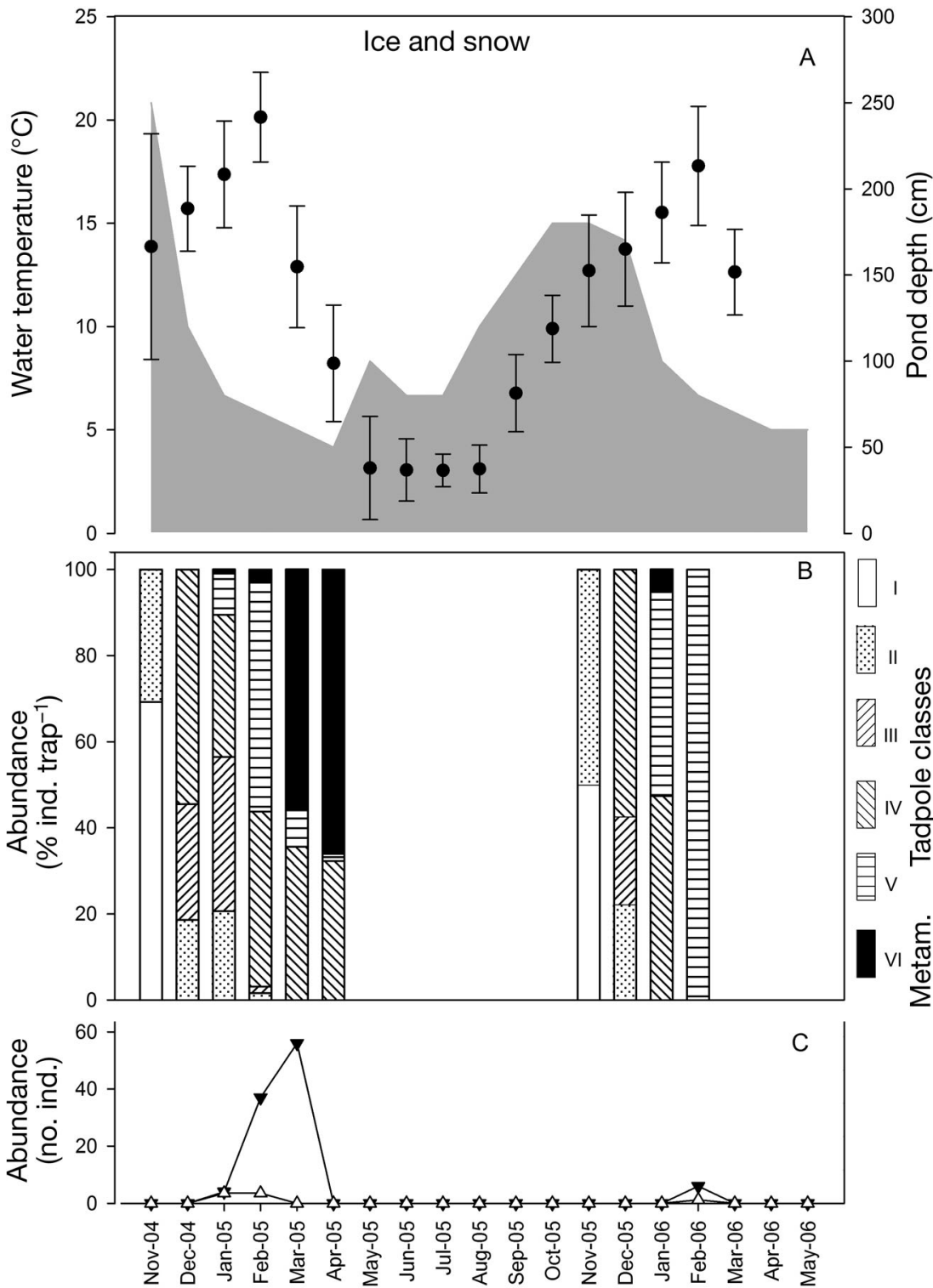

Fig. 1. Atelognathus patagonicus. Environmental data and abundance of developmental classes of $A$. patagonicus in monthly samples at Batea Pond, northwestern Patagonia. (A) Mean ( \pm 1 SD) monthly water temperatures and depth (shaded area). (B) Abundance (\%) of individuals per trap in monthly samples of each developmental class. (C) Abundance (number of individuals) in monthly samples of Class V tadpoles $(\Delta)$ and metamorphs $(\boldsymbol{\nabla})$ captured on transects

related to the highest mean water temperatures during the second study period (Table 1, Fig. 1A,B).

Annual precipitation was $344 \mathrm{~mm}$ in 2004 and $266 \mathrm{~mm}$ in 2005, and as a result, the pond was deeper during the first study period. The time at which each class first appeared and the length of the larval period were correlated to water availability in the pond (Fig. 1A,B). The relative abundance of the earliest stages (Class I) was correlated with the maximum depth of the pond in each period (Table 1, Fig. 1). In contrast, the highest percentage of individuals in advanced stages (Class $\mathrm{V}$ and metamorphs) was correlated to shallower pond depths (Table 1, Fig. 1).

At Verde Pond, the different development classes were represented from April 2004 to May 2006, except for May and October 2005, when no individuals were captured (Fig. 2B). The period of larval development lasted for approximately 6 mo for seasonal tadpoles and $1 \mathrm{yr}$ for overwintering tadpoles. At least 2 development classes coexisted for $88 \%$ of the study period (Fig. 2B).

Few Class I tadpoles were captured in the samples; they were found at percentages $<1 \%$ in January-March 2005 and January 2006, although this increased to $14.7 \%$ in December 2005. Class II tadpoles were recorded in 14 out of 26 months of sampling, with higher percentages in January-March, June-July and December 2005, and at percentages $<1 \%$ in May 2004, April 2005 and February-March 2006. Class III and IV tadpoles coexisted throughout

were recorded in both aquatic and terrestrial samples, and were found from January to April 2005 and in January and February 2006 (Fig. 1B,C).

Tadpoles and metamorphs at Batea Pond were exposed to mean monthly water temperatures that ranged from $8.22 \pm 2.81$ to $20.14 \pm 2.16^{\circ} \mathrm{C}$ (means \pm $1 \mathrm{SD}$; Fig. 1A) There was no significant correlation between development class and mean monthly water temperature; nevertheless, there was a trend towards the occurrence of Class IV and V tadpoles being almost the entire sampling period (23 out of 26 months) in high proportions. The most advanced tadpoles (Class V) were well represented (12 to $58 \%$ ) in the summer months (December-February) for both periods. Metamorphs were captured from November to April (Fig. 2B).

Overall, the relative abundance of individuals differed significantly between development classes and between sampling periods and months (Kruskal-Wallis test, $H=417.02, \mathrm{p}<0.001$ ). Post hoc 
Table 1. Correlation analysis (Spearman test; $\mathrm{r}_{\mathrm{s}}$ ) between the relative abundance of developmental classes of Atelognathus patagonicus and mean monthly water temperatures at Batea and Verde Ponds, and depth at Batea Pond. Developmental classes I-V are tadpoles; VI represents metamorphs. Significant p-values are in bold

\begin{tabular}{|c|c|c|c|c|c|c|c|}
\hline & & & & Develo & tal class & & \\
\hline & & I & II & III & IV & $\mathrm{V}$ & VI \\
\hline \multicolumn{8}{|l|}{ Batea Pond $(\mathrm{n}=10)$} \\
\hline \multirow[t]{2}{*}{ Mean monthly water temperature } & $r_{s}$ & -0.372 & 0.150 & 0.457 & 0.153 & 0.532 & -0.190 \\
\hline & $\mathrm{p}$ & 0.292 & 0.672 & 0.181 & 0.665 & 0.115 & 0.603 \\
\hline \multirow[t]{2}{*}{ Depth } & $\mathrm{r}_{\mathrm{s}}$ & 0.685 & 0.530 & 0.058 & -0.320 & -0.665 & -0.835 \\
\hline & $\mathrm{p}$ & 0.033 & 0.116 & 0.870 & 0.370 & 0.042 & 0.005 \\
\hline \multicolumn{8}{|l|}{ Verde Pond $(n=26)$} \\
\hline \multirow[t]{2}{*}{ Mean monthly water temperature } & $r_{s}$ & 0.619 & 0.494 & 0.288 & 0.552 & 0.836 & 0.786 \\
\hline & $\mathrm{p}$ & 0.001 & 0.011 & 0.152 & 0.004 & $<0.0001$ & $<0.0001$ \\
\hline
\end{tabular}
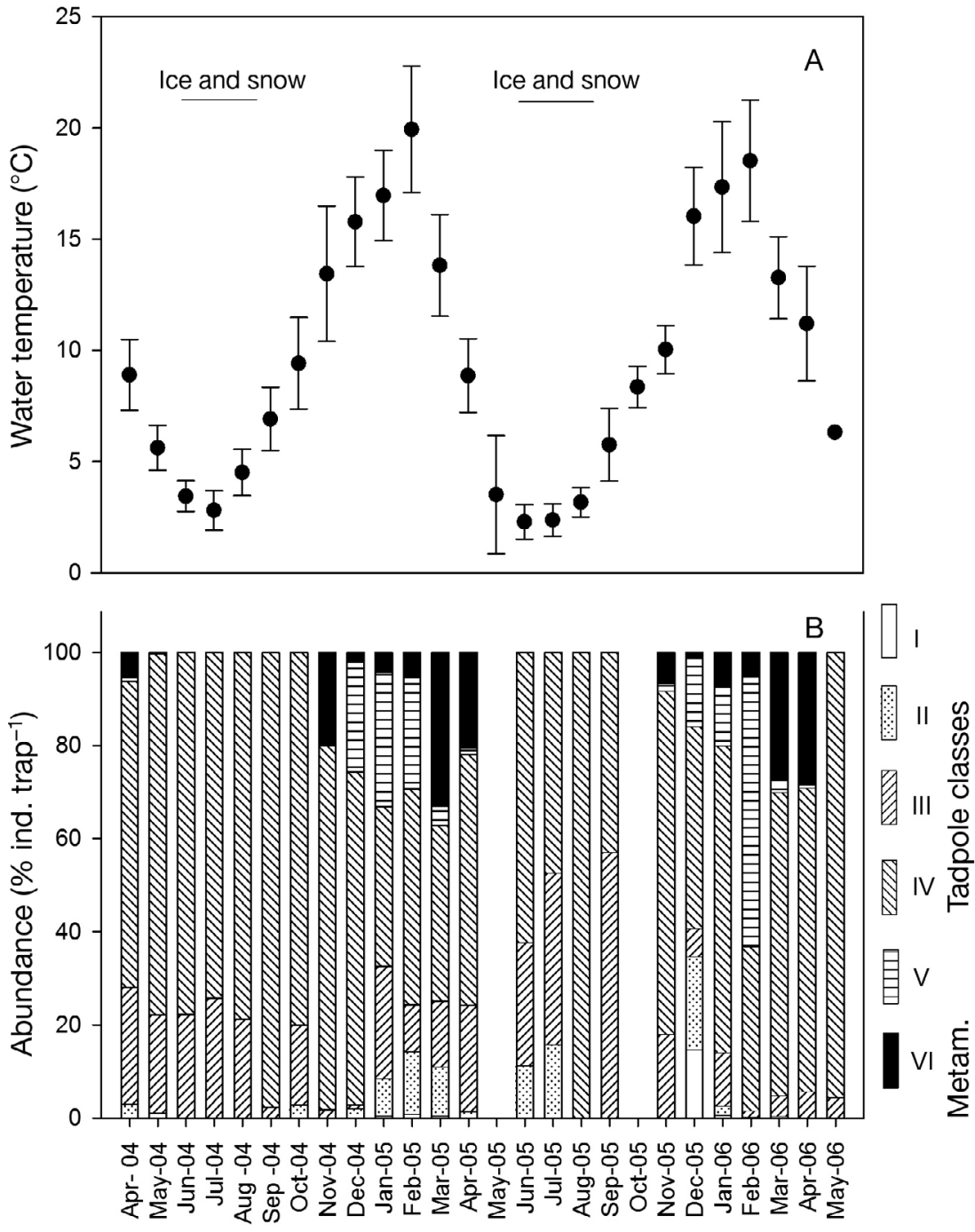

Fig. 2. Atelognathus patagonicus. Environmental data and abundance of developmental classes of $A$. patagonicus in monthly samples at Verde Pond, northwestern Patagonia. (A) Mean $( \pm 1$ SD) monthly water temperatures. (B) Abundance $(\%)$ of individuals per trap in monthly samples of each developmental class comparisons indicated that relative abundance differed significantly between months (Tukey test, $q=$ $26.91, \mathrm{p}<0.05$ ) and between the same months for the 2 sampling periods (Tukey test, $q=15.10, \mathrm{p}<$ 0.05). Between 800 and 948 ind. were captured in May 2004, February 2005 and February 2006. The largest capture $(\mathrm{n}=948$; February 2006) was made up of Classes III, IV and $\mathrm{V}$ and metamorphs.

Almost all of the development classes were represented in the samples from Verde Pond during December, January, February, March and April each year (Fig. 2B).

Overwintering Class V tadpoles captured in both December 2004 and 2005 were larger than the seasonal tadpoles of the same class in February 2005 and 2006, respectively (mean \pm 1 SD: December 2004, 25.08 $\pm 1.46 \mathrm{~mm}$; December 2005, $25.69 \pm$ $1.76 \mathrm{~mm}$; February 2005, $22.94 \pm$ $1.73 \mathrm{~mm}$; February 2006, $23.45 \pm$

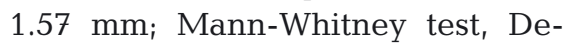
cember 2004 vs. February 2005, $U=$ 231.5, p < 0.009; $t$-test, December 2005 vs. February 2006, $t=4.38, \mathrm{p}<$ 0.001). However, no significant difference was found between the size of metamorphs of the overwintering tadpoles captured in November 2004 and 2005 and the seasonal tadpoles captured in March 2005 and April 2006, respectively (mean \pm 1 SD: 
November 2004, $23.06 \pm 0.71 \mathrm{~mm}$; November 2005, $22.90 \pm 0.81 \mathrm{~mm}$; March 2005, $22.26 \pm 1.21 \mathrm{~mm}$; April 2006, $22.81 \pm 0.8 \mathrm{~mm}$; Mann-Whitney test, November 2004 vs. March 2005, $U=495, \mathrm{p}=0.058$; November 2005 vs. April 2006, $U=376, \mathrm{p}=0.990$ ).

Relative abundance differed significantly between development classes (Tukey test, $q=20.77, \mathrm{p}<0.05$ ) and in the comparison of development classes among months (Tukey test, $q=8.96, \mathrm{p}<0.05$ ) and between periods (Tukey test, $q=15.10, \mathrm{p}<0.05$ ) (Fig. 1B).

For the months in which tadpoles were captured at Verde Pond, mean $( \pm 1 \mathrm{SD})$ monthly water temperatures near the shore ranged from $2.3 \pm 0.8$ to $19.9 \pm$ $2.8^{\circ} \mathrm{C}$ (Fig. 2). A significant positive correlation was found between the relative abundance of tadpoles (Class I, II, IV and V tadpoles and metamorphs) and mean monthly water temperature (Table 1, Fig. 2). In deep water, mean monthly water temperatures ranged from $2.5 \pm 0.02$ to $16.5 \pm 0.1^{\circ} \mathrm{C}$.

A comparison between the populations in the 2 ponds showed differences in abundance for the captures (Kruskal-Wallis test, $H=339.26, \mathrm{p}<0.001$ ). The maximum number of individuals in 1 capture at Verde Pond was 4.1 times higher than that at Batea Pond.

\section{DISCUSSION}

Atelognathus patagonicus has a seasonal breeding pattern, as expected for amphibians in temperate regions of the world (Duellman \& Trueb 1986). This pattern is shown by the presence of small larvae (Gosner stage 26, total length $27 \mathrm{~mm}$ ) in spring and early summer.

The combined effect of latitude $\left(39^{\circ} \mathrm{S}\right)$ and altitude (elevations near $1200 \mathrm{~m}$ ) that characterizes the lagoons inhabited by Atelognathus patagonicus determines the physical climate features of the area, with temperatures lower than $0^{\circ} \mathrm{C}$, frequent frosts and snowfall from mid-autumn to early spring, and is most likely responsible for the seasonal breeding pattern observed. Other sympatric anurans, such as Rhinella spinulosa and Pleurodema bufoninum, also have a seasonal breeding pattern, laying eggs in early spring in temporary creeks (M.E.C. \& C.A.Ú. pers. obs.).

Atelognathus patagonicus breeds in permanent and temporary bodies of water. In the permanent Verde Pond, the presence of small larvae throughout spring suggests that eggs are laid throughout this season, enabling the different development classes to coexist. In this case, tadpoles from early clutches that are capable of undergoing metamorphosis during the same growing season coexist with tadpoles from late clutches that will undergo metamorphosis during the following season. This phenomenon has also been observed in other anuran species in the Northern Hemisphere, such as Lithobates catesbeianus and Glandirana rugosa (Martof 1956, Wilbur \& Collins 1973, Werner \& McPeek 1994). Viparina \& Just (1975) found that about $5 \%$ of $L$. catesbeianus larvae underwent metamorphosis during the same season in which the eggs were laid, while the rest of the cohort overwintered in the larval stage and underwent metamorphosis during the following breeding season. G. rugosa, a species considered to be a prolonged breeder, lays eggs more than once during the breeding season and at the end of the growing season some of the tadpoles undergo metamorphosis while others overwinter (Khonsue et al. 2001).

A harsh environment is a determining factor for breeding events, and the results of this study suggest that the permanence of the ponds might be a crucial factor in the major differences in the development patterns observed in Atelognathus patagonicus.

In the permanent pond (Verde Pond), the population of Atelognathus patagonicus tadpoles was found to deploy a double strategy, namely: (1) some of the tadpoles have a short larval period with metamorphs in the same growing season (seasonal tadpoles) and (2) others overwinter in the pond and undergo metamorphosis the following spring (overwintering tadpoles). In contrast, in the temporary pond (Batea Pond), the reduction of the water column, with the consequent changes in water quality and competition for resources (volume effect), exerts environmental pressure, resulting in tadpoles with a short larval period (Richter-Boix et al. 2011). In Batea Pond, we only recorded seasonal tadpoles that metamorphosed in the summer and autumn, at the end of the hydroperiod, with no record of mortality. Verde Pond had a predominance of seasonal tadpoles during spring and summer, and overwintering tadpoles (established in Classes III and IV) during winter and spring; metamorphs were recorded in late spring, summer and early autumn. The different strategies used by this species, associated with the hydroperiod of the wetlands in which it lives, have been reported for a number of anurans. In Patagonia, for example, A. nitoi, a microendemic frog that inhabits permanent and temporary ponds, has a dual strategy in its larval development (Úbeda et al. 1999, Úbeda 2006).

The results of the present study and that of Cuello \& Perotti (2006) confirm that Atelognathus patagoni- 
cus tadpoles can overwinter in a permanent pond. In addition to Atelognathus, 4 other anuran genera that include species with overwintering tadpoles have been reported in Patagonian environments: Alsodes, Batrachyla, Chaltenobatrachus and Hylorina (Úbeda 1998, Úbeda et al. 1999, Navas et al. 2010, Basso et al. 2011). In short, overwintering tadpoles appears to be a common and successful strategy in Patagonian anurans.

The effect of temperature on the larval development of some anurans has been studied both in the laboratory and in the field (Ultsch et al. 1999), and environmental temperature has been recognized to have a pronounced effect on length of the larval period by virtue of its influence on differentiation and growth rates (Lucas \& Reynolds 1967, Smith-Gill \& Berven 1979, Dupré \& Petranka 1985). We found that the highest water temperature records coincided with the presence of Class $\mathrm{V}$ tadpoles and the first metamorphs. Low temperatures are known to delay differentiation more than growth, thereby increasing stage-specific size (Smith-Gill \& Berven 1979), and cold temperatures might prolong development, as might be the case in Atelognathus patagonicus in permanent ponds. It has been shown that the larvae of Lithobates clamitans that do not complete metamorphosis before the beginning of autumn stop their growth and differentiation (Smith-Gill \& Berven 1979), and resume it the following spring; these larvae ultimately undergo metamorphosis at larger sizes than those that do so during the season in which the eggs are laid (Berven et al. 1979, Smith-Gill \& Berven 1979). We found that Class V overwintering tadpoles in the permanent pond attained larger sizes than the seasonal tadpoles of the same class, confirming this prediction.

Amphibian species that colonize environments with various hydroperiods are expected to have phenotypic plasticity regarding the time range of larval development and growth (Wilbur \& Collins 1973, Newman 1989, Loman \& Claesson 2003). Atelognahtus patagonicus, which breeds and develops in different kinds of ponds, shows its plasticity in the length of larval development, with overwintering tadpoles in the permanent pond and seasonal tadpoles in the temporary pond. We may therefore infer that hydroperiods in these ponds have a strong effect on larval development, although other variables, such as temperature, competition for resources or predation, may also promote these development patterns.

The plasticity to speed up development in environments that are beginning to dry may increase individual survival, while individuals with access to plen- tiful resources in permanent bodies of water can lengthen their development time and undergo metamorphosis at larger sizes (Crump 1989, Denver et al. 1998). In permanent bodies of water, the advantages of remaining in the water longer to attain larger sizes are greater than the advantages of earlier metamorphosis (Wilbur \& Collins 1973). This may give individuals the advantage of attaining sexual maturity at larger sizes (Berven \& Gill 1983, Berven 1990).

Previous studies have reported that most ponds inhabited by Atelognathus patagonicus are permanent (Fox et al. 2005, Cuello et al. 2009a). Since overwintering only occurs in permanent ponds, it may be said to prevail as a development strategy in this anuran species, at least for the period during which the studies were performed. This would explain the success of the species, judging by the high densities found in permanent ponds by Fox et al. (2005). Thus, this kind of strategy may serve as a population reservoir, allowing a species to persist in a given area without the need for immigration and repopulation after a winter kill of adults, and could become an important link in the life history of this species. This theory has been proposed for several species with tadpoles that routinely overwinter in cold-temperate climates, such as Rana muscosa (Bradford 1983), Lithobates catesbeianus (Hulse et al. 2001), L. clamitans (Martof 1956), and other northern ranid species whose tadpoles overwinter less frequently (Collins \& Lewis 1979).

The greater structural complexity observed in the permanent pond may also favor co-occurrence of different development stages and a greater abundance of tadpoles compared with the temporary pond.

Lastly, the notable plasticity in larval development strategies shown by Atelognathus patagonicus would enable it to colonize environments as widely varying as those compared in this study. The information contributed by this work highlights the importance of preserving both temporary and permanent ponds, and ensuring the existence of environments that will allow this species to continue to breed and develop in the face of possible human-related disturbance of its habitat. Temporary ponds with hydroperiods of at least 4 mo should be protected because they are suitable environments for the breeding and development of A. patagonicus. The results of this study, in addition to the results of previous studies that looked at strategies displayed by juveniles and adults (Cuello \& Perotti 2006, Cuello et al. 2006, 2008, 2009b), show the ability of $A$. patagonicus to adapt to changing environments, and its vulnerability to disturbance of its habitat caused by humans. 
Our results reinforce the effort already being made by the National Parks Administration authorities to regulate human activity in Laguna Blanca National Park, in particular by banning the introduction of fish into the fish-free endorheic ponds and controlling the activity of the livestock in and around the ponds. Regarding livestock, a pilot experiment was conducted at Laguna Blanca National Park in which 1 pond was fenced in (Administración de Parques Nacionales 2004). The marginal vegetation on the shores recovered rapidly, providing additional shelter for Atelognathus patagonicus metamorphs. Having confirmed the effectiveness of this management measure, we recommend that it is replicated in other ponds of the national park, to contribute towards regulating the raising of livestock in the park, since this activity has reached a critical point, affecting the normal development of $A$. patagonicus (there is a large number of head of livestock moving about freely). Because livestock raising is the primary means of subsistence for some, and the only means for most, of the 'crianceros' (Administración de Parques Nacionales 1993), any restrictions of this kind should at least take into account and cater for the basic needs of the livestock for water, for example by building watering holes or tanks, and at the same time promote the search for alternative means of income for the local pastoralists. The importance of achieving a balance between the subsistence of native human populations and conservation is recognized worldwide. Nowadays, in this region, there is a tendency to foster the relationship between residents and institutions, a task which, however, meets with great historical and economic difficulties.

This information on the biology and life history of the endemic species Atelognathus patagonicus, which differs from other anuran species present in the area (Rhinella and Pleurodema), is highly relevant for inclusion in management and conservation plans, for both $A$. patagonicus specifically and its habitat more generally. It would be advisable to implement a monitoring program of both larval and juvenile/adult stages as part of the general conservation plan to be applied in Laguna Blanca National Park.

Acknowledgements. We thank M. Calvo, P. Casanovas and A. L. Iglesias for their work as field assistants; park rangers of Laguna Blanca National Park and technicians from Delegación Regional Patagonia of Administración de Parques Nacionales (APN) for supporting our field work; and C. Chehébar and C. Arosteguy for their valuable comments on the manuscript. We also thank the anonymous reviewers and the editor for their helpful suggestions. This project was partly supported by research grants from Universidad Nacional del Comahue (B124 and B153), Wildlife Society Conservation (Research Fellowship Program) and Rufford Small Grant for Nature Conservation. Capture of specimens was authorized by APN (Disp. DNCAP No 55/04).

\section{LITERATURE CITED}

Administración de Parques Nacionales (1993) Plan General de Manejo. Resolución 65/94. Parque Nacional Laguna Blanca. Delegación Técnica Regional Patagonia, Administración de Parques Nacionales, Buenos Aires

Administración de Parques Nacionales (2004) Delegación Técnica Regional Patagónica. Aprobación IMA. Disposición 101/04, San Carlos de Bariloche

Basso NG, Úbeda CA, Bunge MM, Martinazzo LB (2011) A new genus of neobatrachian frog from southern Patagonian forests, Argentina and Chile. Zootaxa 3002:31-44

Basso NG, Úbeda CA, Martinazzo L, Cuello ME (2012) Atelognathus patagonicus (Gallardo, 1962). Rana de Laguna Blanca. In: Categorización del estado de conservación de la herpetofauna de la República Argentina. Ficha de los Taxones. Anfibios. Cuad Herpetol 26(Supl 1):173

Berven KA (1990) Factors affecting population fluctuations in larval and adult stages of the wood frog (Rana sylvatica). Ecology 71:1599-1608

Berven KA, Gill DE (1983) Interpreting geographic variation in life-history traits. Am Zool 23:85-97

Berven KA, Gill DE, Smith-Gill SJ (1979) Countergradient selection in the green frog, Rana clamitans. Evolution 33: 609-623

> Bradford DF (1983) Winterkill, oxygen relations, and energy metabolism of a submerged dormant amphibian, Rana muscosa. Ecology 64:1171-1183

Cei JM, Roig VG (1966) Los caracteres biocenóticos de las lagunas basálticas del oeste de Neuquén. Bol Estud Geogr 13:182-201

Collins JP (1979) Intrapopulation variation in the body size at metamorphosis and timing of metamorphosis in the bullfrog, Rana catesbeiana. Ecology 60:738-749

> Collins JP, Lewis MA (1979) Overwintering tadpoles and breeding season variation in the Rana pipiens complex in Arizona. Southwest Nat 24:371-373

Crump ML (1989) Effect of habitat drying on developmental time and size at metamorphosis in Hyla pseudopuma. Copeia 1989:794-797

Cuello ME, Perotti MG (2006) Atelognathus patagonicus. Overwintering tadpoles. Herpetol Rev 37:441

Cuello ME, Bello MT, Kun M, Úbeda CA (2006) Feeding habits and their implications for the conservation of the endangered semiaquatic frog Atelognathus patagonicus (Anura, Neobatrachia) in a northwestern Patagonian pond. Phyllomedusa 5:67-76

Cuello ME, Úbeda CA, Bello MT (2008) Relationship between morphotypes of Atelognathus patagonicus (Anura, Neobatrachia) and environmental conditions: evidence and possible explanation. Phyllomedusa 7: $35-44$

> Cuello ME, Perotti MG, Iglesias GJ (2009a) Dramatic decline and range contraction of the endangered patagonian frog, Atelognathus patagonicus (Anura, Leptodactylidae). Oryx 43:443-446

Cuello ME, Úbeda CA, Bello MT, Kun M (2009b) Seasonal trophic activity of the aquatic morphotype of Atelog- 
nathus patagonicus (Anura, Neobatrachia) and prey availability in the littoral benthos of a permanent pond in Argentinean Patagonia. Phyllomedusa 8:135-146

Daciuk J (1968) La fauna del Parque Nacional Laguna Blanca (Estudio zoo-ecológico preliminar). Anales de Parques Nacionales 11:225-302

Denver RJ, Mirhadi N, Phillips M (1998) Adaptive plasticity in amphibian metamorphosis: response of Scaphiopus hammondii tadpoles to habitat desiccation. Ecology 79: 1859-1872

Duellman WE, Trueb L (1986) Biology of amphibians. McGraw-Hill, New York, NY

> Dupré RK, Petranka JW (1985) Ontogeny of temperature selection in larval amphibians. Copeia 1985:462-467

- Fox SF, Yoshioka JH, Cuello ME, Úbeda C (2005) Status, distribution, and ecology of an endangered semi-aquatic frog (Atelognathus patagonicus) of northwestern Patagonia, Argentina. Copeia 2005:921-929

Gallardo JM (1979) Importancia de la conservación de las faunas de anfibios y reptiles. Acta Zool Lilloana 34: 102-106

Gosner KL (1960) A simplified table for staging anuran embryos and larvae with notes on identification. Herpetologica 16:183-190

Griffiths RA (1997) Temporary ponds as amphibian habitats. Aquat Conserv 7:119-126

Hulse AC, McCoy CJ, Censky EJ (2001) Amphibians and Reptiles of Pennsylvania and the Northeast. Cornell University Press, Ithaca, NY

Khonsue W, Matsui M, Hirai T, Misawa Y (2001) Age determination of wrinkled frog, Rana rugosa with special reference to high variation in postmetamorphic body size (Amphibia: Ranidae). Zool Sci 18:605-612

Krebs CJ (1989) Ecological methodology. Harper Collins Publishers, New York, NY

Laurila A, Kujasalo J (1999) Habitat duration, predation risk and phenotypic plasticity in common frog (Rana temporaria) tadpoles. J Anim Ecol 68:1123-1132

Loman J, Claesson D (2003) Plastic response to pond drying in tadpoles Rana temporaria: test of cost models. Evol Ecol Res 5:179-194

Lucas EA, Reynolds WA (1967) Temperature selection by amphibian larvae. Physiol Zool 40:159-171

Martof B (1956) Growth and development of the green frog, Rana clamitans, under natural conditions. Am Midl Nat 55:101-117

Mazzucchelli SA (1991) Parque Nacional Laguna Blanca. Relevamiento preliminar de las comunidades acuáticas. Delegación Técnica Regional Patagonia. Administración de Parques Nacionales, Bariloche

- Navas CA, Úbeda CA, Logares R, Jara FG (2010) Thermal tolerances in tadpoles of three species of Patagonian anurans. South Am J Herpetol 5:89-96

Editorial responsibility: Michael Mahony,

Callaghan, Australia
Newman RA (1989) Developmental plasticity of Scaphiopus couchii tadpoles in an unpredictable environment. Ecology 70:1775-1787

Ortubay S, Cussac V, Battini M, Barriga J, Aigo J, Alonso M, and others (2006a) Is the decline of birds and amphibians in a steppe lake of northern Patagonia a consequence of limnological changes following fish introduction? Aquat Conserv 16:93-105

Ortubay S, Cussac V, Battini M, Barriga JP, Aigo J, Candarle $\mathrm{P}$, and others (2006b) Laguna Blanca, restauración ecológica, uso racional y pesca artesanal. Desde la Patagonia. Difundiendo Saberes 4:30-35. www.desdela patagoniads.com.ar/

Pechmann JHK, Scott DE, Whitfield Gibbons J, Semlitsch $\mathrm{RD}$ (1989) Influence of wetland hydroperiod on diversity and abundance of metamorphosing juvenile amphibians. Wetlands Ecol Manag 1:3-11

Perotti MG, Jara FG, Úbeda CA (2011) Adaptive plasticity of life-history traits to pond drying in three species of Patagonian anurans. Evol Ecol Res 13:415-429

Richter-Boix A, Tejedo M, Rezende EL (2011) Evolution and plasticity of anuran larval development in response to desiccation. A comparative analysis. Ecol Evol 1: $15-25$

Semlitsch RD (1987) Relationship of pond drying to the reproductive success of the salamander Ambystoma talpoideum. Copeia 1987:61-69

> Smith-Gill SJ, Berven KA (1979) Predicting amphibian metamorphosis. Am Nat 113:563-585

Úbeda CA (1998) Batracofauna de los bosques templados patagónicos: un enfoque ecobiogeográfico. PhD thesis, Universidad de Buenos Aires, Buenos Aires, Argentina

Úbeda C (2006) La rana del Challhuaco: biología y conservación. Desde la Patagonia. Difundiendo Saberes 4: 16-20. www.desdelapatagoniads.com.ar/

Úbeda C, Zagarese H, Díaz M, Pedrozo F (1999) First steps towards the conservation of the microendemic Patagonian frog Atelognathus nitoi. Oryx 33:59-66

Úbeda C, Lavilla E, Basso N (2010) Atelognathus patagonicus. In: IUCN 2011. The IUCN Red List of Threatened Species v.2011.2. www.iucnredlist.org

Ultsch GR, Bradford DF, Freda J (1999) Physiology. Coping with the environment. In: McDiarmid RW, Altig R (eds) Tadpoles. The biology of anuran larvae. The University of Chicago Press, Chicago, IL, p 189-214

> Viparina S, Just JJ (1975) The life period, growth and differentiation of Rana catesbeiana larvae occurring in nature. Copeia 1975:103-109

Werner EE, McPeek MA (1994) Direct and indirect effects of predators of two anuran species along an environmental gradient. Ecology 75:1368-1382

Wilbur HM, Collins JP (1973) Ecological aspects of amphibian metamorphosis. Science 182:1305-1314

Submitted: December 29, 2012; Accepted: October 2, 2013 Proofs received from author(s): December 18, 2013 